\title{
Carbohydrate Polymers for Green Multi-Purpose Mortar
}

\author{
Rr. M. I. Retno Susilorini ${ }^{1 *}$, Riska Suryanto², Yehuda Pramana ${ }^{2}$ \\ ${ }^{1}$ Department of Infrastructure and Environmental Engineering, Faculty of Environmental Science and Technology, \\ Soegijapranata Catholic University, Jl. Pawiyatan Luhur IV/1, Bendan Dhuwur, Semarang 50234, Indonesia \\ ${ }^{2}$ Department of Civil Engineering, Faculty of Engineering, Soegijapranata Catholic University, Jl. Pawiyatan Luhur IV/1, \\ Bendan Dhuwur, Semarang 50234, Indonesia
}

*Corresponding author: ORCID 0000-0001-8531-7485

\begin{abstract}
Concrete and mortar polymer have been developed to gain high strength and durability. Instead of chemical polymer, organics polymer is widely used as material innovation. This research aims to investigate the performance as well as its compressive strength of carbohydrates polymer for multi-purposes mortar with amylum powder and honey to be used for multi-purpose mortar. There were 285 cubes of mortar specimens 50 × 50 × $50 \mathrm{~mm}$ with basic composition weight ratio of cement $:$ sand $:$ water $=1: 1: 0.6$ with addition of amylum powder and honey tested for compressive strength. The result found optimum composition of specimen series is KT-M-0-G which contains honey $0.03 \%$ and amylum $0.1 \%$ of cement weight with compressive strength of $37.44 \mathrm{MPa}$. The comparison of compressive strength of mortar in current investigation to the previous researches as reference has shown higher compressive strength of specimen series without honey but very low compressive strength to specimen series with honey. This research confirms that mortar with carbohydrates polymer can be used for multi-purpose mortar because it has high performance of strength and durability.
\end{abstract}

Keywords: carbohydrate polymer, green, multi-purpose, mortar.

\section{INTRODUCTION}

Polymer mortar and concrete widely used because of its high performance and functionality as well as sustainability [1]. In certain composites, polymer used as co-binder because it works together with Portland cement [2]. Generally, the use of polymer is important to improve the mechanic properties such as compressive strength, bond mechanism, setting time, water absorption, vibration damping, etc [3]. Some chemical and organic polymers have been used and developed to gain high performance of mortar and concrete [3-10]. However, there is still an uncertainty about the performance of organic polymer mortar as green material (spending less energy than chemical ones) which has high performance and durability as well as the chemical ones, as it is debatable to claim that polymer concrete or mortar will gain maximum strength at short or long term [11].

Carbohydrates polymer mortar and concrete researches [10][12][13] have been carried out to confirm the advantage of carbohydrates polymer for multi-purposes mortar as investigated in this research [13]. Carbohydrates polymers used in this research were amylum powder and honey. Amylum powder used is rice flour manufactured product that has advantage of high viscosity, gelatinization, and amylase content [14] which contributes great bonding mechanism and compactness. The use of honey for admixture has been popular because of its 'sugar effect' which increased the compressive strength of mortar and concrete [15][16], since honey contained $38.4 \%$ of fructose and $30.3 \%$ of glucose [17]. Those previous researches reported that carbohydrates polymer mortar have good compressive strength in aggressive environment such as seawater, brackish water, and tidal flood water [13] while carbohydrates polymer concrete have good compressive and tensile strength [10], [12]. Hence, this research aims to investigate the performance of carbohydrates polymer for multi-purposes mortar with amylum powder and honey to be used for green multi-purpose mortar. It is also questioned whether the compressive strength of the specimens will be higher compared to previous investigations.

\section{MATERIALS AND METHODS}

\section{II.I. Materials}

Mortar specimens comprised of 285 cubes of $50 \times 50 \times 50$ $\mathrm{mm}$ with basic composition weight ratio of cement : sand : water $=1: 1: 0.6$. Carbohydrate polymers added into mortar were amylum powder and honey (Fig 1 and Fig 2). Mix design of mortar detailed by Table 1 .

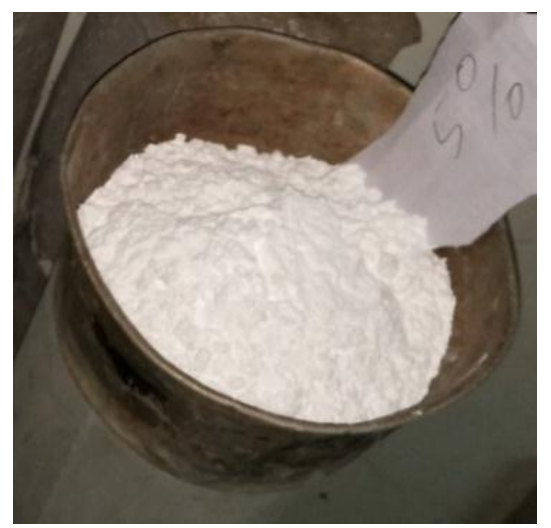

Fig 1. amylum powder which was rice flour manufactured product 


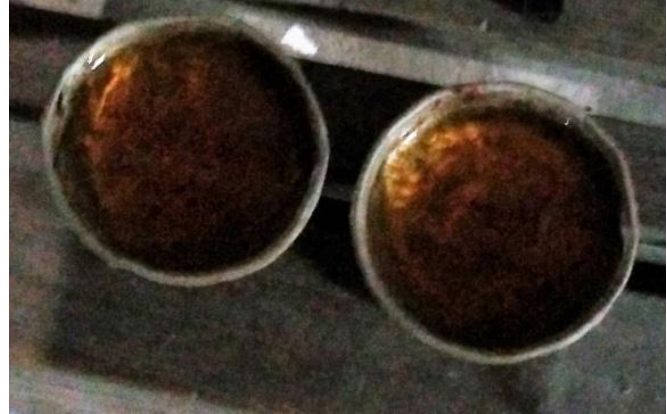

Fig 2. Honey

Table 1. Mortar mix design

\begin{tabular}{|c|c|c|c|}
\hline \multirow{2}{*}{$\begin{array}{l}\text { specimen } \\
\text { code }\end{array}$} & honey & amylum & \multirow{2}{*}{$\begin{array}{c}\text { total } \\
\text { specimens }\end{array}$} \\
\hline & \multicolumn{2}{|c|}{ (\% of cement weight) } & \\
\hline KT-M-0-A & 0 & 0.1 & 15 \\
\hline KT-M-0-B & 0 & 0.2 & 15 \\
\hline KT-M-0-C & 0 & 0.5 & 15 \\
\hline KT-M-0-D & 0 & 1 & 15 \\
\hline KT-M-0-E & 0 & 2 & 15 \\
\hline KT-M-0-F & 0 & 5 & 15 \\
\hline KT-M-0-G & 0.03 & 0.1 & 15 \\
\hline KT-M-0-H & 0.03 & 0.2 & 15 \\
\hline KT-M-0-I & 0.03 & 0.5 & 15 \\
\hline KT-M-0-J & 0.03 & 1 & 15 \\
\hline KT-M-0-K & 0.03 & 2 & 15 \\
\hline KT-M-0-L & 0.03 & 5 & 15 \\
\hline KT-M-0-M & 0.3 & 0.1 & 15 \\
\hline KT-M-0-N & 0.3 & 0.2 & 15 \\
\hline KT-M-0-O & 0.3 & 0.5 & 15 \\
\hline KT-M-0-P & 0.3 & 1 & 15 \\
\hline KT-M-0-Q & 0.3 & 2 & 15 \\
\hline KT-M-0-R & 0.3 & 5 & 15 \\
\hline $\begin{array}{l}\text { KT-M-0-S } \\
\text { (control) }\end{array}$ & 0 & 0 & 15 \\
\hline & Tot & gecimens & 285 \\
\hline
\end{tabular}

\section{II.II. Experimental Program}

After curing, all specimens were tested for compressive strength with Compression Machine CO-325 (Fig 4) that referred to ASTM C109 Standard Test Method for Compressive Strength of Hydraulic Cement Mortars. Compressive strength may be calculated by Equation (1).

$$
\sigma=\frac{\mathrm{P}}{\mathrm{A}}
$$

Where:

$$
\begin{array}{ll}
\sigma & =\text { compressive strength }(\mathrm{MPa}) \\
\mathrm{P} & =\text { load }(\mathrm{kN}) \\
\mathrm{L} & =\text { cross-section area }(\mathrm{mm} 2)
\end{array}
$$

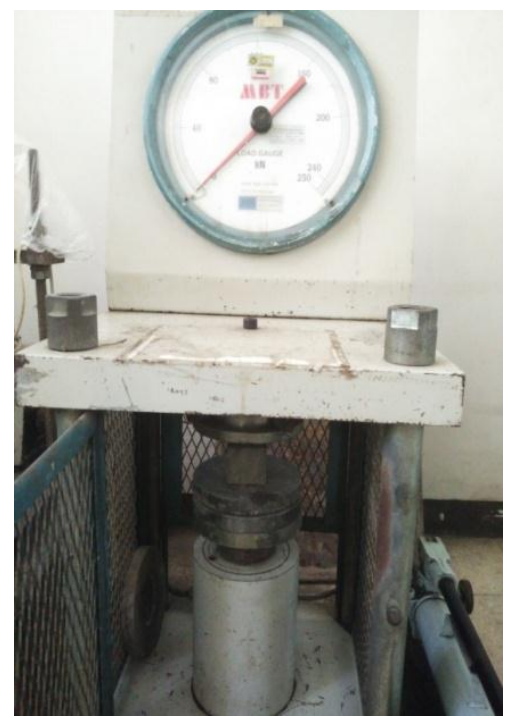

Fig 4. Compression Testing Machine

\section{RESULTS AND DISCUSSION}

Mortar specimens were produced (Fig 5) that were tested for compression test and getting broken in many various pattern (Fig 6). Current investigation found the compressive strength development of most specimens as described by Fig 7 to Fig 10 as modified from [18].

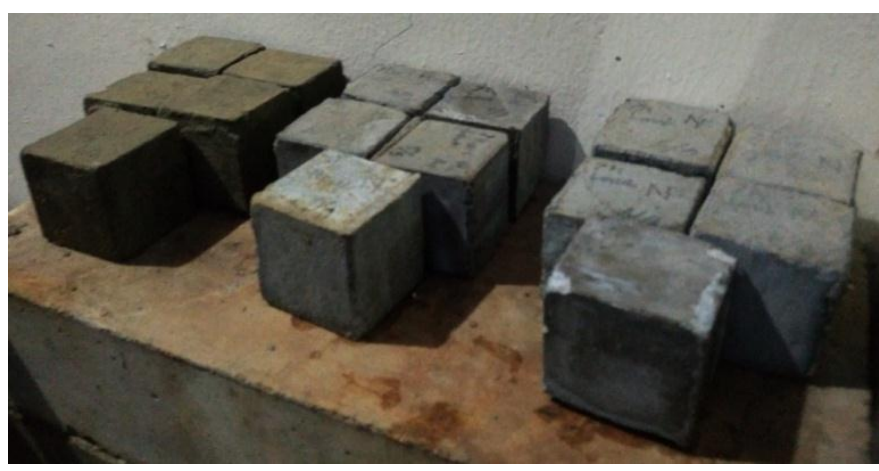

Fig 5. Mortar specimens

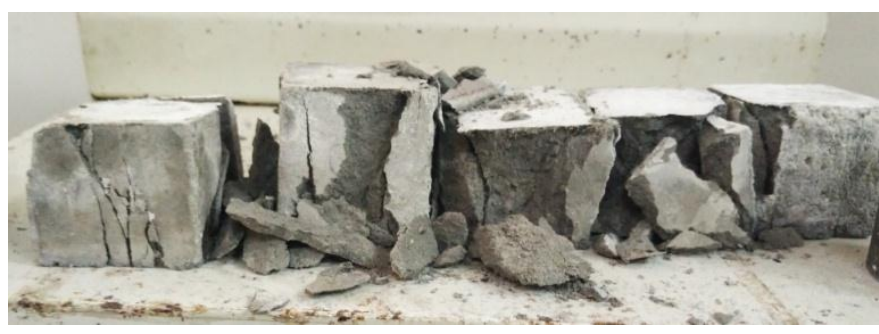

Fig 6. Broken mortar specimens after compressive test

Fig 7 describes compressive strength of specimen series without honey that increase from age 7 days to 28 days respectively. It was found that KT-M-0-E achieved highest compressive strength of $33.44 \mathrm{MPa}$. Specimen series with honey $0.03 \%$ of cement weight also performed good development of compressive strength as shown by Fig 8 . 
Highest achievement was found on specimen KT-M-0-G of 37.44 MPa. Different behaviour found for specimen series with honey $0.3 \%$ of cement weight that there was no data available for compressive strength of the specimens at age 7 and 14 days. The unavailability of data caused by collapse specimens at testing because of softens mortar cubes.

Compressive strength of all series of specimens has shown interesting phenomenon as described by Fig 9. High compressive strength of specimens found at KT-M-0-A to KT-M-0-G series of specimens without honey and one series of specimen (KT-M-0-H) with honey of $0.003 \%$ of cement weight. After that series, the development of compressive strength has gradually decreased at the rest series of specimens with honey $0.03 \%$ of cement weight. The compressive strength of specimens has fallen down started at KT-M-0-M to KT-M-0-R series where specimens contain honey of $0.3 \%$ of cement weight. It was noted that the highest compressive strength of KT-M-0-G of $37.44 \mathrm{MPa}$ was $10.90 \%$ higher compared to control specimen KT-M-0-S of $33.76 \%$ MPa.

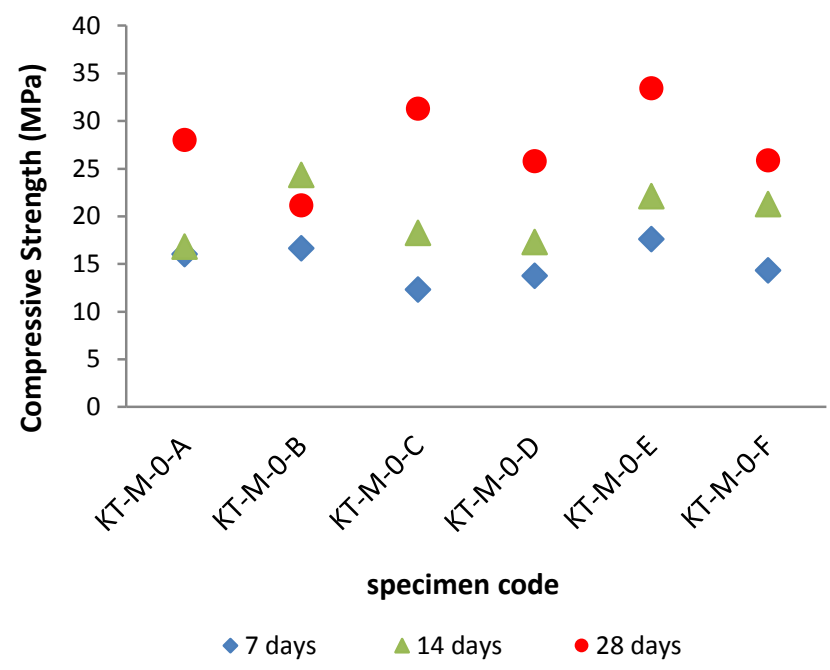

Fig 7. Compressive strength of specimen series without honey modified from [18])

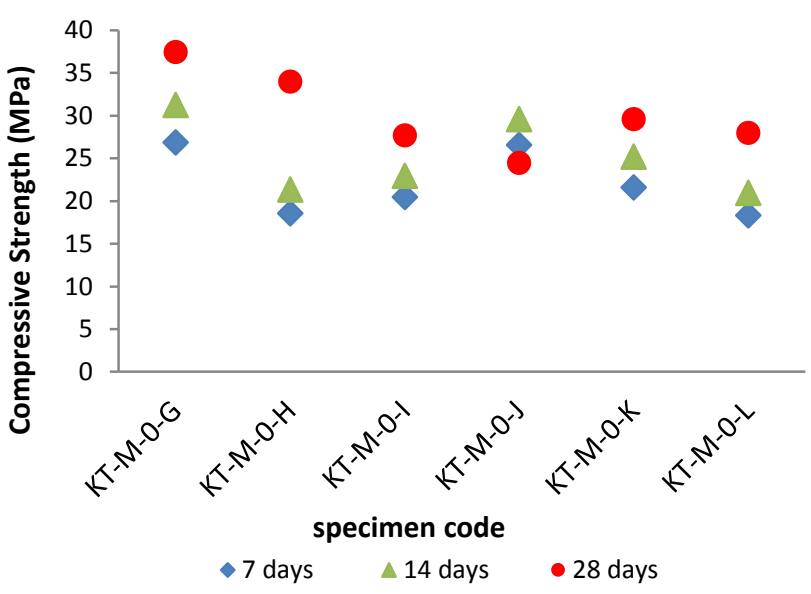

Fig 8. Compressive strength of specimen series with honey of $0.03 \%$ of cement weight (modified from [18])

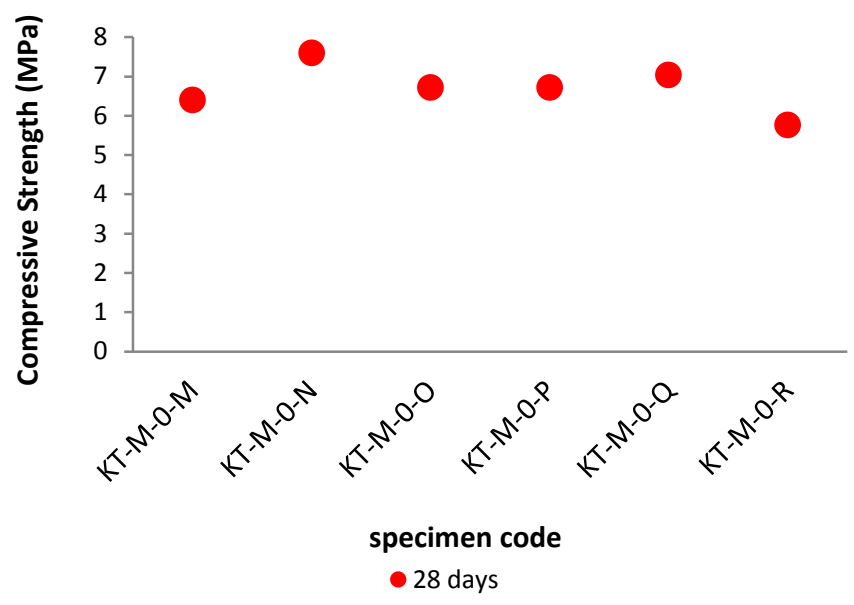

Fig 9. Compressive strength of specimen series with honey of $0.3 \%$ of cement weight (modified from [18])

Previous researches [10][12][13] have reported compressive strength of concrete and mortar in aggressive environment curing (seawater, brackish water, and also tidal flood water), with addition of the same carbohydrates polymers, amylum powder and honey. Those investigations have become good reference for this current investigation as shown by Fig 11 . The comparison of compressive strength of mortar in current investigation to the previous researches as reference has shown higher compressive strength of specimen series without honey (KT-M-0-A to KT-M-0-G). This performance didn't work with series specimens with honey $(0.03 \%$ and also $0.3 \%$ of cement weight) that the compressive strength of those specimens series decreased and even jumped down. It was also interesting that specimen series without honey have higher compressive strength compared to concrete specimens but have fallen down for specimen series with honey.

Optimizing the composition of specimen series may carried out by analysing data of Fig 12 and Fig 13. The data of Fig 12 has shown the highest compressive strength achieved by specimen series with honey $0.03 \%$ of cement weight and amylum $0,1 \%$ of cement weight. It was also found at Fig 13 that amylum $0.1 \%$ of cement weight had higher compressive strength with honey $0.03 \%$ of cement weight. Therefore, optimum composition of specimen series is KT-M-0-G which contains honey $0.03 \%$ and amylum $0.1 \%$ of cement weight with compressive strength of $37.44 \mathrm{MPa}$. 


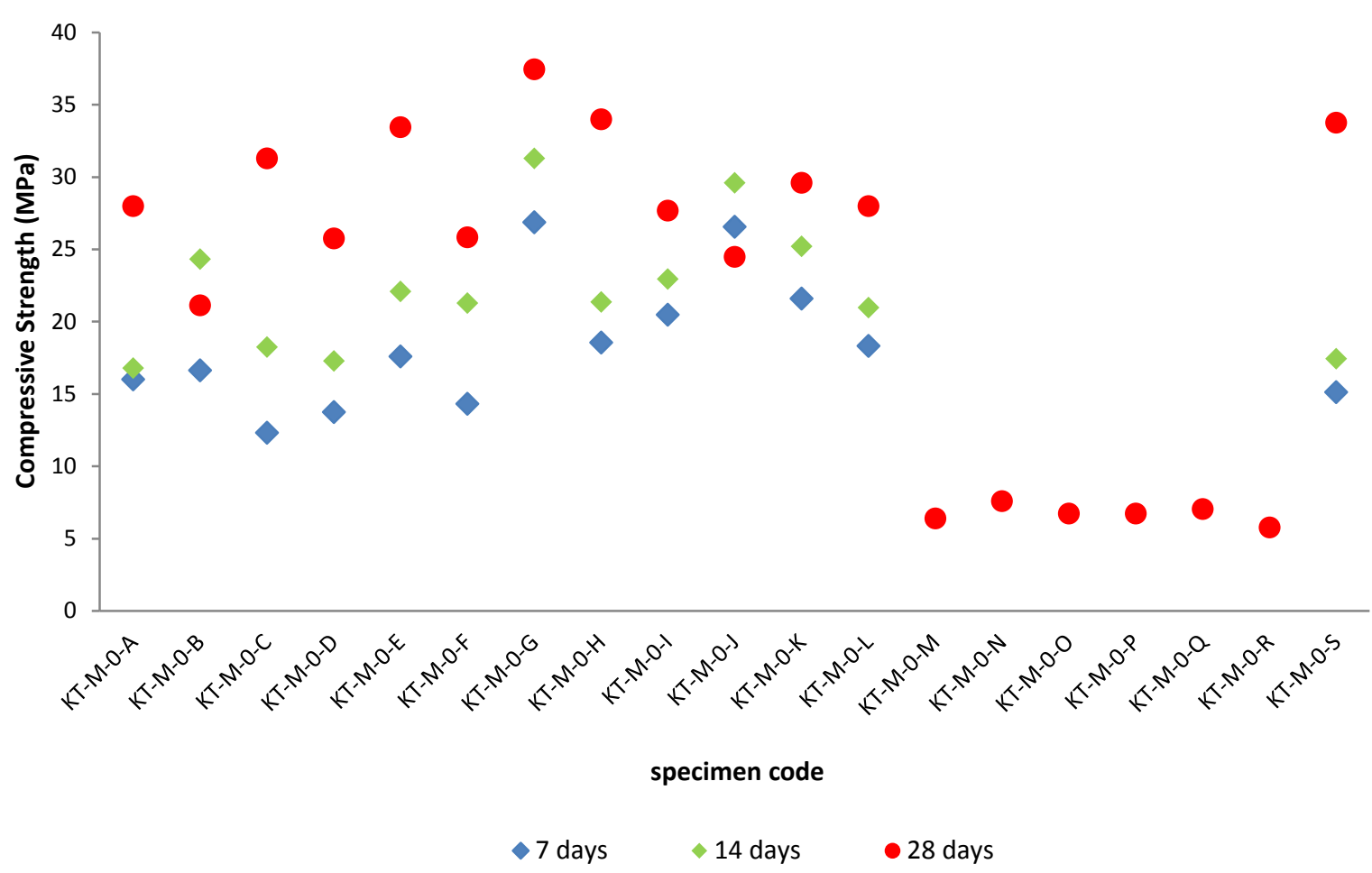

Fig 10. Compressive strength of all specimens (modified from [18])

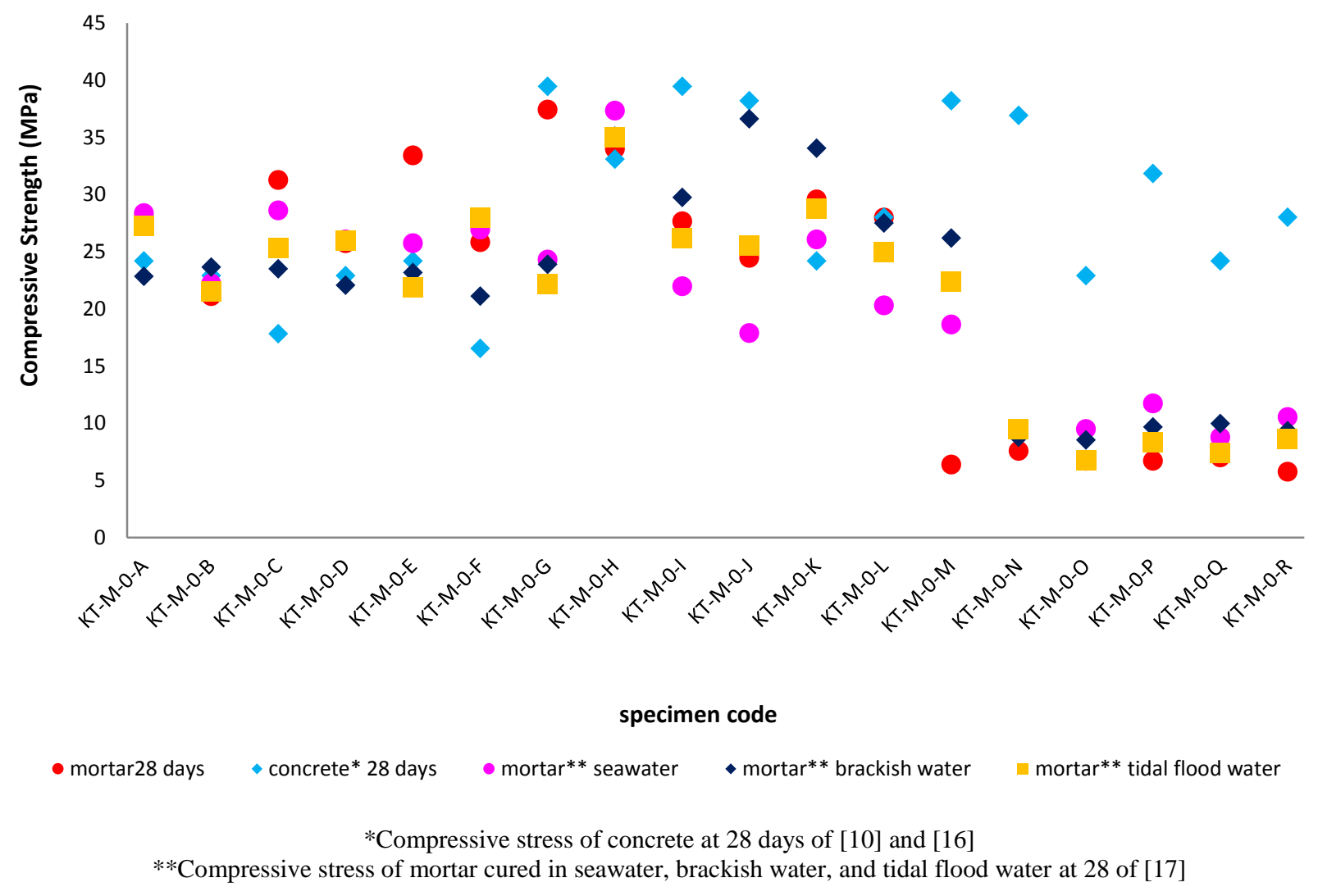

Fig 11. Comparison of compressive strength of specimens of current investigation and several researches $(*, * *)$ 


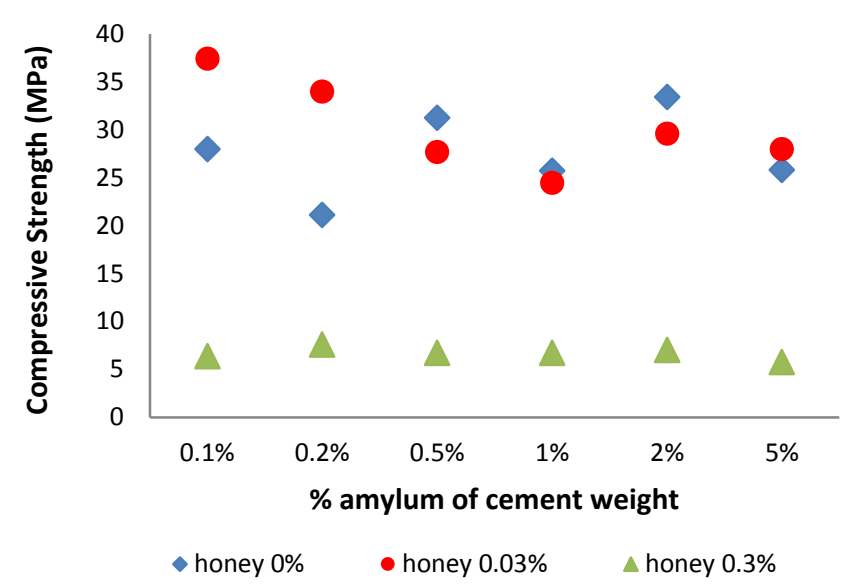

Fig 12. Compressive strength of specimens with function of $\%$ honey of cement weight

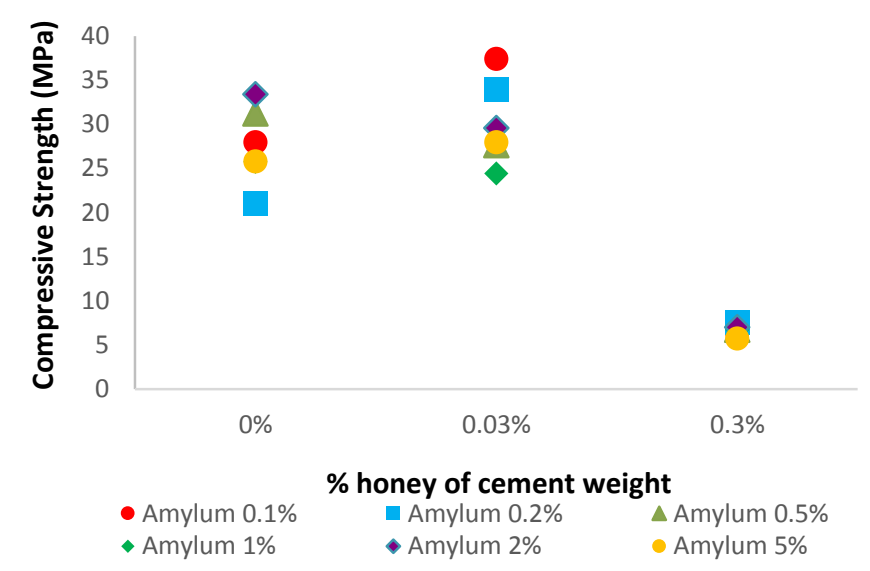

Fig 13. Compressive strength of specimens with function of $\%$ amylum of cement weight

\section{CONCLUSION}

KT-M-0-G is optimum composition which contains honey $0.03 \%$ and amylum $0.1 \%$ of cement weight with compressive strength of $37.44 \mathrm{MPa}$. It is found that compressive strength of mortar in current investigation to the previous researches as reference has shown higher compressive strength of specimen series without honey but very low compressive strength to specimen series with honey.

The findings of this research have proven that mortar with carbohydrates polymer can be used for multi-purpose mortar because it has high performance of strength and durability. For normal condition of this current investigation, carbohydrates polymer mortar gives advantage of high compressive strength.

\section{ACKNOWLEDGMENT}

The authors gratefully acknowledge support and funding from Ministry of Research, Technology, and Higher Education, Republic of Indonesia, by grants of INSINAS Riset Pratama Individu Grant Second Year 2018 (Contract No. 35/INS1/PPK/E4/2018).

\section{REFERENCES}

[1] Ganesan, S., Othuman Mydin, M.A., Sani, N.M., Che Ani, A.I. Performance of polymer modified mortar with different dosage of polymeric modifier. MATEC Web of Conferences. 2014. 15(June 2017). DOI:10.1051/matecconf/20141501039.

[2] Lukowski, P. Studies on the Microstructure of EpoxyCement Composites. Archives of Civil Engineering. 2016. 62(2). Pp. 101-113. DOI:10.1515/ace-2015-0068.

[3] Negim, E.S., Rimma, N., Bekbayeva, L., Akmaral, U., Herki, B.M., Merey, N., Rinat, I., Yeligbayeva, G. Effect of methyl cellulose/poly(acrylic acid) blends on physico-mechanical properties of Portland cement pastes. Oriental Journal of Chemistry. 2017. 33(1). Pp. 450-457. DOI:10.13005/ojc/330152.

[4] Momtazi, A.S., Khoshkbijari, R.K., Mogharab, S.S. Polymers in Concrete : Applications and Specifications. Journal of Natural and Social Sciences. 2015. 3(3). Pp. 62-72. URL: europeanscience.com/eojnss_proc/article/view/4427/2149.

[5] Susilorini, R.M.I.R., Rejeki, V.G.S., Santosa, B., Caresta, F.D., Putro, M.S. Polymer modified mortar with bonding adhesive agent for column repairing in tidal flooding prone area. AIP Conference Proceedings. 2018. 1977. DOI:10.1063/1.5042969.

[6] Susilorini, R.M.I.R., Santosa, B., Rejeki, V.G.S., Riangsari, M.F.D., Hananta, Y.D. The increase of compressive strength of natural polymer modified concrete with Moringa oleifera. AIP Conference Proceedings. 2017. 1818. DOI:10.1063/1.4976923.

[7] Susilorini, R.M.I.R., Suwarno, D., Santosa, B., Putra, L.H., Kurniawan, E. Rebound Hammer Test result of old repaired masonry wall using premixed mortar additive in tidal flooding prone area. AIP Conference Proceedings. 2018. 1977(June). Pp. 1-6. DOI:10.1063/1.5042982.

[8] Susilorini, R.M.I.R., Hardjasaputra, H., Sri, T., Galih, H., Reksa, W.S., Ginanjar, H., Joko, S. The advantage of natural polymer modified mortar with seaweed: Green construction material innovation for sustainable concrete. Procedia Engineering. 2014. 95(Scescm). Pp. 419-425. DOI:10.1016/j.proeng.2014.12.201.

[9] Susilorini, R.R.M.I.R., Vidayanti, D., Fitra, H.A., Santosa, B. Can we adapt to tidal flooding? AIP Conference Proceedings. 2019. 2114(June). DOI:10.1063/1.5112454.

[10] Rr. M. I. Retno Susilorini, Budi Santosa, N. Febri Satrio, R.P.B. Compressive and Splitting Tensile Strength of Polymer Modified Concrete Using Amylum and Honey. Journal of Engineering and Applied Science. 2018. 13(17). Pp. 7192-7197. DOI:http://dx.doi.org/10.3923/jeasci.2018.7192.7197.

[11] Sokolowska, J.J. Long-term compressive strength of polymer concrete-like composites with various fillers. 
International Journal of Engineering Research and Technology. ISSN 0974-3154 Vol.13, No.3 (2020), pp. 580-585

(C) International Research Publication House. https://dx.doi.org/10.37624/IJERT/13.3.2020.580-585

Materials. 2020. 13(5). Pp. 9-11.

DOI:10.3390/ma13051207.

[12] Nugroho, F.S., Rizalditya, P.B. 1393-3814-1-Pb. 1(2). Pp. 96-108.

[13] Prasetyo, N.I., Arsa, G., Abiyoga, A., Retno, R.M.I., Santosa, B. Durabilitas Mortar Polimer Termodifikasi Alami dengan Amylum dan Bahan Tambah Madu. 2018. 2. Pp. 26-32.

[14] Leewatchararongjaroen, J., Anuntagool, J. Effects of Dry-Milling and Wet-Milling on Chemical, Physical and Gelatinization Properties of Rice Flour. Rice Science. 2016. 23(5). Pp. 274-281. DOI:10.1016/j.rsci.2016.08.005.

[15] Suraj Shah, A. V, Rupesh Kadam, A.R. Effect of Sugar and Jaggery on Workability and Compressive Strength of Concrete. 2018. (March).

[16] Chand, J.D.S. Effect of Sugar on The Compressive Strength of Concrete. 2015. 5(4). Pp. 5-7.

[17] Ball, D.W. The Chemical Composition of Honey. Journal of Chemical Education. 2007. 84(10). Pp. 1643. DOI:10.1021/ed084p1643.

URL: https://doi.org/10.1021/ed084p1643.

[18] Suryanto, R., Pramana, Y. The Use of Amylum Carbohydrates Polymer and Honey Admixture to Increase Compressive Strength of Natural Mortar Modified Polymer (Penggunaan Polimer Karbohidrat Amylum Dan Bahan Tambah Madu untuk Meningkatkan Kuat Tekan Mortar Polimer Termodifikasi Alami). Undergraduate Thesis, Department of Civil Engineering, Faculty of Engineering, Soegijapranata Catholic University, Semarang, Indonesia, 2018 